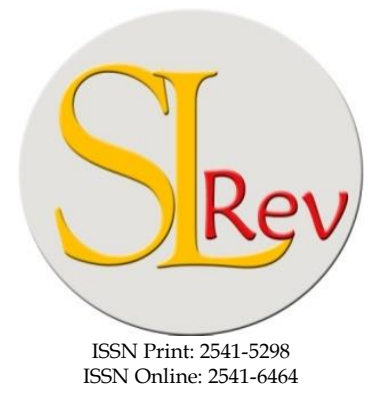

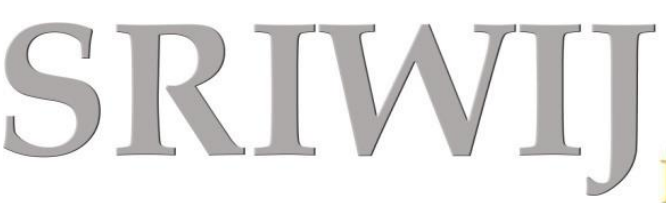
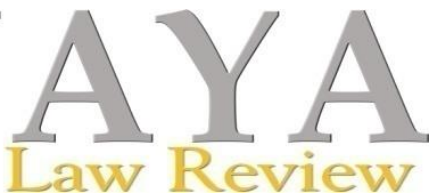

Editorial Office: Faculty of Law, Sriwijaya UniversityJalan Srijaya Negara, Palembang, South Sumatra 30139, Indonesia.

Phone: +62711-580063Fax: +62711-581179

E-mail: sriwijayalawreview@unsri.ac.id|sriwijayalawreview@gmail.com

Website: http://journal.fh.unsri.ac.id/index.php/sriwijayalawreview

\title{
The International Cooperation to Eradicate Illicit Firearms Trafficking in Southeast Asian Region
}

\author{
Syahmin $\mathrm{AK}^{*}$ and Fidelia*
}

\begin{abstract}
The term of illicit firearms trafficking used by the United Nations is a movement of illegal trade in firearms controlled by organised criminal groups. Such movement specifically in ASEAN region is against national and regional laws. Hence, the growth in illegal firearms trade increases concern to the Southeast Asian countries. The article aims to examine effort to eradicate illegal firearms trafficking in ASEAN countries. Statute method combined with case approach in Southeast Asian Countries is employed in this research. The findings of the research indicate that the ASEAN countries have utilized diplomatic means namely the ASEAN Regional Forum (ARF) and the establishment of ASEAN Police (ASEANAPOL). These forums propose by ASEAN Political-Security Community (APSC) in a way to coordinate among the chief of national police of ASEAN countries including, inter alia, law enforcement policies, criminal courts and transnational crimes to combat crimes committed in the ASEAN region. In fact, the effectiveness of the APSC is still in question because the illicit firearms trafficking cannot be demolished.
\end{abstract}

Keywords: Eradication; Illicit Arms Trafficking; International Cooperation; Southeast Asia.

\section{ARTICLE HISTORY:}

\section{DOI: 10.28946/sIrev.Vol2.Iss2.121.pp183-192}

Received: Feb 21, 2018;

Reviewed: Jul 19, 2018;

Accepted: Jul 27, 2018;

Published: Jal 31, 2018;

Citation: V.2.2 SLRev. 2018.

* Faculty of Law, Universitas Sriwijaya. E-mail: syahminak57@gmail.com

\section{INTRODUCTION}

The obligations of the state are not only limited to various domestic affairs, but also includes relations with other countries. The relationship is established in the form of cooperation intended to achieve the common goals or interests of sovereign and equitable countries. ${ }^{1}$ The cooperation pro-

Abu Daud Busroh, Ilmu Negara, Jakarta: Bumi Aksara, 8, 2015, p170. duced several forms of inter-state's community interests, such as economic and trade, political and security and sociocultural relationship.

In globalization era, the rapid technological development causes the distance among the countries are borderless. Communication and information exchange can be performed quickly. The emergence of information and communication technology can be used as an instrument by the criminals to intensify their operations both on the domestic and global level.

Friedman $^{2}$ is of the opinion that technology encourages globalization involving

2 Thomas L. Priedman was a writer of six "The Best Seller" books and awarded three "Pulitzer" and was also a reporter. (http://www.thomaslfriedman.com/bookshelf/the-lexus-and-theolive-tree) (retrieved: March 30, 2017). 
global integration even further the world turns to be a global village. Nevertheless, the effect of cross-border relationships has caused communities, states, and governments are unable to assure the safety of all individuals, economic growth, social protection, or even individual rights and increased transnational crimes.

According to Parthiana, ${ }^{3}$ the term transnational crime is to indicate the existence of national crimes which contains an international aspect. It means that there are crimes that occur within the boundaries of a country (national), but in some cases are related to the interests of other countries, so that there appear to be two or more countries which concerned or are related to the crimes.

It should be emphasized that transnational crime has never been given a specific definition because it is intended to reach all activities undertaken for profit and done in an unlawful way. ${ }^{4}$ Nevertheless, in 1995 , the UN has identified 18 forms of transnational crimes, namely ${ }^{5}$ money laundry, terrorism, theft of art and cultural objects, theft of intellectual property, illicit arms trafficking, aircraft hijacking, sea piracy, insurance fraud, computer crimes, environmental crimes, human trafficking, illegal human organ trafficking, illicit drug trafficking, fraudulent bankruptcy, infiltration of illegal business, corruption, bribery of public officials, and other offences committed by organized criminal group.

In addition, ASEAN has also identified six transnational crimes, namely terrorism,

I Wayan Parthiana, Hukum Pidana Internasion$a l$, Bandung: CV. Yrama Widya, 2016, p32.

4 LPSK, "Transnational Organized Crime," Buletin Kesaksian LPSK No. III Tahun 2012, p5.

5 www.undoc.org/undoc/en/organizedcrime/index.html (retrieved: March 30, 2017). narcotics trade, illegal firearms trading, money laundering, human trafficking, and sea piracy. ${ }^{6}$ The issue of illegal arms trade re-emerged after terrorist attack in Sarinah, Indonesia reported using illegal weapons obtained from countries in Southeast Asia ${ }^{7}$.

Southeast Asia has long military conflict history making Southeast Asia a promising area of operations for the perpetrators to commit their crimes especially illegal arms trade until 8 August 1967 when these countries finally establish Association of Southeast Asian Nations (ASEAN). In its development, ASEAN began to think of the next step of this organization, the creation of various political and economic agenda such as ZOPFAN ${ }^{8}$ and TAC $^{9}$ which became the foundation for the Southeast Asian countries to coexist peacefully. A big challenge for Southeast Asian Countries to prevent, fight and eradicate illegal firearms trade, where ASEAN is a strategic area, especially since there is no specific regulation for it.

It should be emphasized in this article that the study is focusing on the issue of the challenges or obstacles facing ASEAN as a regional organization in Southeast Asia to

6 ASEAN, ASEAN Documents on Combating Transnational Crime and Terrorism, Jakarta: ASEAN Secretariat, 2012, p9.

7 http://nasional.sindonews.com/read/1077829/14 /proses-distribusi-senpi-dari-filipina-ke-terorissarinah-ditelusuri-1453042076 (retrieved: 20 April 2017).

8 ZOPFAN was a declaration signed by the Foreign Minister from five ASEAN countries in Kuala Lumpur in 1971. The Declaration dealt with the freedom of intervention from outside Powers and extended the cooperation of the ASEAN countries member.

9 TAC was an agreement signed by the Head of the States in the South East Asian Region, concluded in Bali in 1967. The objective of the agreement was, inter alia, to promote the friendship and cooperation amongst the people from the ASEAN. 
prevent, fight, and combat illegal arms trade. In addition, the issue of how do ASEAN countries collaborate to prevent, fight, and combat illegal arms trade will also be the scope of this article.

\section{RESEARCH METHOD}

The type of research used is normative or legal research. In this study, the authors use a statute approach, comparative approach as well as historical approach. This research is included in the type of qualitative research where the authors use literature study to collect information relevant to the topic or problem that becomes the object of research.

This analysis presents explanations of materials and other information to address the question of these issues relating to the issue of fire arms trafficking in Southeast Asia, and the role of ASEAN as a regional organization to cooperate in economic, social, cultural and security fields. Furthermore, it will be seen how far the success of ASEAN Cooperation to eradicate illicit arms trafficking in Southeast Asia region.

\section{ANALYSIS AND DISCUSSION Illicit Firearms Trafficking}

David Capie, ${ }^{10}$ argue that there are three typologies to distinguish the arms trade, namely trade regulated by law, illegal weapon trading or through the black market, and pseudo trading. Then, Keith Krause $^{11}$ subdivided trading regulated by law into three: (1) Trade by military or police forces of each country; (2) Nongovernmental parties (both are not from the government, licensed exporters and import-

10 David Capie, Small Arms Production and Transfers in Southeast Asia, Sydney: Strategic and Defence Studies Centre Australian National University, 2012, p20.

11 Note 29. ers, (3) government with foreign governments. The trade is carried out by government and government selling and buying weapons produced by legal state-owned enterprises and the process of transactions is through a treaty contract.

The main difference between the illegal firearms trading and the pseudo firearms trading is the participation of the government in its transactions. The illicit arms trade is a completely unlawful transaction and no government knows about the transaction, the pseudo arms trade is a type of transactions in which the legality of the government's involvement in the transaction is confidential and questionable. This kind of transactions is arranged in such a way by the government to look like a legal transaction, because there is a justification set by the authorities, and there are actually other criminal acts in this pseudo trade of weapons.

Furthermore, various firearms should also be mentioned in this study. Guns are tools used to fire bullets, projectiles, and can cause explosions. The weapon is a device used to fire bullets, projectiles, and can cause explosions. United Nations' Panel for arms issues has categorized weapons such as revolvers, pistols, assault rifles, and machine guns as conventional weapons. The organization also classifies conventional weapon as grenades and portable explosive devices which are easily to carry.

In addition, conventional weapons commonly used by members of the military, rebel forces, and private use are classified mass destruction weapon as long as they are dangerous and deadly weapons. The categorisation as mass destruction weapon because it has multiple destructive abilities compared to conventional weapons 
that can generally kill only one person in a single shot. The weapons of mass destruction can obliterate one city and one civilization in a single shot.

The mass destruction weapons according to the UN consist of the missile, biological weapon, chemical weapon, and nuclear weapon. ${ }^{12}$ Thus, illegal firearm trade can cause a crime that supports violence and increase the level of human suffering in the situation of conflicts around the world. ${ }^{13}$ Illegal firearm trade is also known to have adverse effects on human security, its development and human rights, whether it is the right to have a good life, or for life itself. So it needs an instrument to combat illegal firearm trade based on UN Small Arms Conferences in 2006. ${ }^{14}$ The fact of global issues shows that every minute there are civilians who die from firearms (both legal and illegally owned). This reality is supported by the arms trade in the free market that reaches $10-20 \%$ of the total arms trade in the world. Meanwhile, in Southeast Asia, illegal weapons are responsible for more than 500,000 people die each year. All these deaths are caused by illegally obtained firearms. It indicates that this type of crime is increasingly threatening the security of ASEAN member countries. ${ }^{15}$ Moreover, the profit from illegal arms trafficking

12 http://www.un.org/disarmament/wmd/nuclear (retrieved: 24 April 2017).

13 Elli Kytomaki dan Valerie Yankey-Wayne, Five Years of Implementing the United Nations Programme of Action on Small Arms and Light Weapons, Regional Analysis of National Reports UNIDER, 2006, p13.

14 Read Small Arms Conference Review Section II "Preventing, Combating and Eradicating the Illicit in small arms and light weapons in all its aspects", Sub Section "Level Regional".

15 Pan Khan Khup Hango, The Arms Trade Treaty: Implication for Southeast Asia, RSIS Commentaries No. 106/2013, 2013, p1. reaches 2 - 10 billion US dollars per year, ${ }^{16}$ making the perpetrators of illegal arms trade increasingly incentive to commit the crime. It is a big challenge for countries in the region to prevent, fight, and combat illegal firearms trade in ASEAN which is a strategic area, moreover, there has not been a specific regulation for it.

\section{Regulation on Organized Transnational Crime}

Transnational crime has never been given a definition in order to quickly identify the existence of new crimes that potentially become a transnational organized crime. The United Nations Convention Against Transnational Organized Crime states that a crime is categorized as an organized transnational crime if the offense is committed by more than one state territories; committed in one country, but the preparation, planning, direction or control of the offense is carried out in the territory of another country; committed in a territory of a state, but involves an organized group of offenders who commit offenses in more than one state territories; or committed in a territory of a state, but the consequences of such offenses are felt in other countries.

Thus, based on the above explanation, the definition of a transnational crime is a crime committed by individuals who associate and operate across national borders in order to gain power, influence, monetary and/or commercial gains, and is committed in a way that is illegal in a whole or in part. They do so in a pattern that is corruptive and/or full of violence.

Furthermore, there are several international conventions relating to transnational

16 http://www.globalissues.org (retrieved: April 24, 2017). 
crimes especially in the 20th century, among others: 1) United Nations Convention against Transnational Organized Crime. It is a summary of conventions that are peculiar to a crime. The signing of This Convention is a comprehensive international treaty, as it does not deal with a crime only, but many crimes that are considered transnational organized crimes; 2) In addition, ASEAN Declaration on Transnational Crime is an international cooperation in the form of a declaration, which can be interpreted as a form of awareness of each ASEAN member state that the problem of transnational crime is already very global, even at the regional level; 3) ASEAN Declaration on the Prevention and Control of Transnational Crimes.

Both of these ASEAN declarations aims: 1) to improve national and regional capabilities in following up transnational crimes in Southeast Asia; 2) to develop effective strategies aimed at defeating the economic power and criminal organization, as well as damaging the relationship of the criminal organization with other criminal networks, followed by developing a special mechanism so that in the end it can bring these criminals to justice; and 3) to strengthen the capacity of law enforcement and court personnel and enhancing their abilities through a special training on transnational crimes, money laundering, and other related crimes.

\section{Southeast Asia's Regional Cooperation}

Southeast Asia is a place of origin from the longest civil war. ${ }^{17}$ This region is also one of the territories that are torn apart by the

17 https://id.globalvoices.org/2012/07/20/asiatenggara-tempat-asal-dari-perang-sipilterpanjang/ (retrieved: April 24, 2017). war on the face of the earth. At the end of World War II, a stigma appeared in Southeast Asia that a conflict is a fascinating spectacle or story, so dramatization performed by the media at the time of the conflict got more attention from the public making the countries in Southeast Asia which at that time required cooperation to strengthen the political, security, economic and socio-cultural situation forget the conflict of interest that occurred in this region.

Finally, the nations of Southeast Asia were aware that the conflict that had been considered a spectacle would become dangerous if allowed to be a continuous conflict. So, many leaders of the nations in Southeast Asia proposed some forms of cooperation as outlined in the Bangkok Declaration of the $8^{\text {th }}$ of August 1967, in order to resolve the conflicts that existed in this region. In this connection, the UN Charter itself $^{18}$ wants a regionalism, because regional cooperation is an international cooperation which is easier to establish to achieve our common goals because the geographical closeness can bring up an ideal inspiration for the lives of the nations and the states.

As a new development which promised a welfare for the people in Southeast Asia, at the ASEAN Summit in Kuala Lumpur in 1997, ASEAN agreed to develop an integrated region of Southeast Asian community that is open, peaceful, stable and prosperous, caring, tied together in a dynamic partnership in 2020. The expectation was set forth in the Vision of ASEAN 2020. Furthermore, to realize that expectation, ASEAN endorsed Bali Concord II at the $9^{\text {th }}$ ASEAN Summit in Bali in 2003 which ap-

18 Article 51 and 52, the UN Charter. 
proved the establishment of ASEAN Community or more popularly called MEA, ${ }^{19}$ through three pillars, namely the PoliticalSecurity (ASEAN Political-Security Community), the Economic (ASEAN Economic Community), and Socio-Culture (ASEAN Socio-Cultural Community). ${ }^{20}$ In order for this ASEAN Community to be realized, it is necessary to establish connectivity (ASEAN Connectivity). This connectivity will connect ASEAN both from the transport network to the people. ${ }^{21}$ Thus, the ASEAN entity as a regional organization will remain relevant and may become a solid collective identity in the future. ${ }^{22}$

Various official documents issued by ASEAN on the ASEAN Community, the three pillars are proposed to be a new paradigm to build a more advanced region in line with the demands of the future changes by realizing, among others, ${ }^{23}$ in the context of the security community to be achieved, ASEAN will resolve disagreement among member states not by violence or by the threat of violence. The ASEAN community in security-politics is needed by ASEAN to

19 Bacrul Chairi, Menjadi Juara di Era MEA 2015, Jakarta: Dirjen Kerjasama Perdagangan Internasional Kementerian Perdagangan RI, 2015, p3.

20 Lisbet, Masalah-masalah di Kawasan Menjelang Realisasi Komunitas ASEAN 2015: Peluang Indonesia di Komunitas ASEAN 2015, Cetakan Pertama, Jakarta: Pusat Pengkajian Pengelolaan Data dan Informasi (P3DI) Sekretariat Jenderal DPR-RI, 2014, p77.

21 Master Plan on ASEAN Connectivity Association Asian Nations. Available from: http://www.mfa.fo.th/asean/contents/files/aseanmedia-center-2012-2013-182010-779067.pdf (retrieved: April 25, 2017).

22 Faustinus Andrea, 2012, "Tinjauan Perkembangan dan Global: Tantangan Kemitraan Strategis AIPA Menghadapi ASEAN 2015" in Jurnal CSIS, 41 (3), p342.

23 C.P.F Luhulima, Southeast Asia Dynamics Towards 2015, First Print, Jakarta: Center for Political Research (P2P) LIPI, 2010, p67. respond to issues such as transnational crime, poverty and illegal Fishing that often occur in the Southeast Asian region. ${ }^{24}$ In determining the norms of cooperation the ASEAN Political-Security Community remains committed to the principle of nonintervention, decision-making based on consensus, national and regional resilience, mutual respect for national sovereignty, avoidance of threats or use of force, and peaceful settlement of differences or disputes. The concept used refers to the UN Charter and the principles of international law. ${ }^{25}$

In addressing to security issues, ASEAN made the ASEAN Regional Forum set in 1993 as its vanguard. ARF as the only body under ASEAN that is specifically designed to address security issues in Southeast Asia, to carry out its function of creating conflict resolution. However, it is a mean to cooperate with countries to create peace and security not only in Southeast Asia but also in East Asia and Oceania. ARF discusses, among other things, the political situation and the general security of the region such as the issue of nuclear proliferation, the Korean Peninsula, the spread of hand-held weapons and light weapons, missile defence, and maritime security.

24 Athiqah Nur Alami, 2011, "Profile and Orientation of Foreign Policy of Indonesia Post New Order", Journal of Political Research, 8 (2), p179.

25 Cooperation in security includes: (1) conflict prevention/ confidence building measures (CBM); (2) The strengthening of the ASEAN Regional Forum/ARF process: (3) Handling nontraditional security issues (pirates, piracy against vessels, piracy and smuggling, etc.); (4) strengthening ASEAN cooperation in disaster management and emergency response; (5) the promotion of transparency and understanding of defense policy and security perceptions. (ASEAN Community Blueprint 2015). 
In addition, ASEAN also established a Forum of Cooperation for the Chief of National Police of ASEAN member countries (ASEANAPOL) to discuss and coordinate in the exchange of knowledge and skills, law enforcement policies, criminal courts and transnational crimes in order to promote cooperation more effectively in combating crimes committed in the ASEAN region, especially in this case regarding "Illicit Arms Trafficking".

The formation of ASEANAPOL is inseparable from ICPO-INTERPOL as a side line of the $49^{\text {th }}$ ICPO-INTERPOL General Assembly in November 1980 in Manila, Philippines. Originally formed under the name of ASEAN Police Forces, but then renamed ASEANAPOL. From 20 to 24 October 1981, five ASEAN Police Chiefs held the first ASEANAPOL meeting in Manila, Philippines. The objectives of the ASEANAPOL are to combat international crimes in the ASEAN region, to exchange criminal information quickly and accurately, to handle "Hot Pursuit" against crossborder criminals, to exchange personnel in the context of mutual understanding and drawing on one another's experienced, to cooperate in the area of education and police of technology.

ASEANAPOL itself is indeed expected to be a very powerful 'Law Enforcer' that can suppress and even eradicate some transnational crimes, including illegal weapons trade, the addition of troops in some border areas is also a special concern of ASEANAPOL, because according to ASEAN the border area is a very vulnerable area used by smugglers and even illegal arms traffickers to launch the action.

\section{ASEAN's Obstacles and Challenges in Eradicating Illicit Firearms Trafficking Efforts}

The world's illegal arms trafficking is concentrated in areas indicated by armed conflict, violence, war, and organized crime, which are areas that have a high demand for firearms. The history of Southeast Asia as a conflict-prone area is also a latent problem for the region, because of the historical factor, there are still many armed organizations, insurgents, and even terrorists in Southeast Asia, making ASEAN should be more concerned about this issue.

According to Bitzinger, ${ }^{26}$ argue that ASEAN's weakness as well as obstacles in its efforts to combat illegal arms trafficking is ASEAN's habit that rarely issues political-strategic policies, especially in the field of security and defence, so that in 2016 ASEAN as a regional international organization that has existed for almost 50 years still lagged behind the two regional organizations of the Americas and Europe. The regional organizations of the European Region (EU) and the United States (OAS) have long had a legal instrument that clearly regulates the ATT (Arms Trade Treaty), so that their member countries know what form of arms trade is ideal that is desired by their regional organizations, so as to make significant improvements in their regional political, legal, and security affairs.

In the region of Southeast Asia, the attention to the issue of arms trade has actually increased among ASEAN member countries, such as Indonesia, the Philippines, and Singapore, but they only focus on the issues related to the use of firearms used in other

26 Summarised from the interview of the author to interview Richard Bitzinger through Google Mail, April 25, 2017. 
transnational crimes, such as narcotics trafficking and terrorism. Particular attention is certainly needed by ASEAN member countries to issues such as the increasing volume of weapons availability in Southeast Asia. According to Iskandar Hasan and Nina Naramurti, ${ }^{27}$ the potential for conflicts caused by the use of weapons, illegal activities in trade, as well as the arms trade of nongovernmental parties which in fact increases the likelihood of tensions in the region, will eventually trigger the conflict that leads to the destruction political stability and security of the Southeast Asian region.

There have been several attempts made by ASEAN to combat the arms trade, but once again the authors affirm that the efforts made by ASEAN appear to be less serious, it is shown by ASEAN's attitude that never focuses on one issue about political, legal, and security, the discussion is always done generally. For example, the ASEAN Ministerial Meeting on Transnational Crime (AMMTC) was held in Yangon on $23^{\text {rd }}$ of June $1999,{ }^{28}$ an inter-ministerial meeting reported as the first meeting of high-ranking officials of ASEAN member countries discussing the issue of transnational organized crime. It is not only illegal weapons trade, but also some forms of transnational organized crimes that have been identified by the UN before, so in the end, some other crimes were also identified by ASEAN as a form of organized transnational crimes.

\footnotetext{
27 Iskandar Hasan and Nina Naramurti, Kerjasama Kepolisian dan Penegakan Hukum Internasional, Jakarta: PT. Firris Bahtera Perkasa, 2013, p41.

28 Note 38, p42.
}

\section{CONCLUSION}

Based on the findings and the aforementioned analysis, it can be concluded that ASEAN as an international organization in Southeast Asia has several obstacles and challenges in its efforts to prevent, fight and combat illegal arms trafficking. The obstacles, such as ASEAN's habit that rarely issues political-strategic policies, especially in the field of security and defence, second, that the efforts made by ASEAN appear to be half-serious (less serious), it is shown by ASEAN's attitude that never focuses on one issue about political, legal, and security, the discussion is always done generally.

Moreover, there are still fewer ASEAN member countries ratifying ${ }^{29}$ the Arms Trade Treaty (ATT) of the United Nations. ${ }^{30}$ The main obstacle of countries in Southeast Asia region in the implementation of ATT is the absence of standardization conducted by ASEAN as an international organization in the region.

Instead about challenges, ASEAN has just succeeded in establishing the ASEAN Regional Forum and ASEANAPOL to discuss and coordinate in the exchange of knowledge and ability, law enforcement policy, criminal court and transnational crime in order to promote a more effective cooperation to combat crimes committed in the ASEAN region, particularly on Illicit

29 It means that a state must be bound to implement in a good faith the convention. Nurhidayatuloh, et al., 2018, "Forsaking Equality: Examine Indonesia's State Responsibility on Polygamy to the Marriage Rights in CEDAW," Jurnal Dinamika Hukum, Vol. 18 (2), pp182-192.

30 The International conventions have been used as a reference to create several legislations. Annalisa Yahanan, Febrian, and Rohani Abdul Rahim, 2017, "The Protection of Consumer Rights for Aviation Safety and Security in Indonesia and Malaysia”, Sriwijaya Law Review, 1 (1), pp2743. 
Arms Trafficking. ASEAN as an international organization in the Southeast Asian region may become a facilitator for its member countries in every effort to prevent, fight and eradicate "Illicit Arms Trafficking".

\section{REFERENCES}

Alami, Athiqah Nur. 2011. "Profil dan Orientasi Kebijakan Luar Negeri Indonesia Pasca Orde Baru." Journal of Penelitian Politik. 8 (2).

Andrea, Faustinus. 2012. "Tinjauan Perkembangan dan Global: Tantangan Kemitraan Strategis AIPA Menghadapi ASEAN 2015". Journal of CSIS. 41 (3).

ASEAN. 2012. ASEAN Documents on Combating Transnational Crime and Terrorism. Jakarta: ASEAN Secretariat. Tahun 2012.

Busroh, Abu Daud. 2015. Ilmu Negara. Cet. 8. Jakarta: Penerbit Bumi Aksara.

Fleurant, Aude., Sam Perlo-Freeman, Pieter D. Wezeman and Siemon T. Wezeman. 2016. Trends in International Arms Transfers, 2015. Stockholm: SIPRI.

Capie, David. 2012. SmallArms Production and Transfers in Southeast Asia. Sydney: Strategic and Defence Studies Centre Australian National University.

Departemen Luar Negeri Republik Indonesia. 2010. ASEAN Selayang Pandang Edisi ke - 20. Jakarta: Departemen Luar Negeri Republik Indonesia.

Departemen Luar Negeri Republik Indonesia. 2011. Ayo Kita Kenali ASEAN. Jakarta: Departemen Luar Negeri Republik Indonesia.

Direktorat Jenderal Kerjasama ASEAN Departemen Luar Negeri Republik Indonesia. 2010. ASEAN Selayang Pandang Edisi ke 19. Jakarta. Departemen Luar Negeri Republik Indonesia.
Garner, Briyan A. (Ed). 2004. Black's Law Dictionary. 8th Edition. West Publishing.

Guggenheim, Harry Frank. 2005. The HFG Review: Small Arms and Light Weapons: A Call for Research. HFG Foundation.

Hango, Pan Khan Khup. 2013. The Arms Trade Treaty: Implication for Southeast Asia. RSIS Commentaries No. 106/2013. Year of 2013.

Hasan, Iskandar and Nina Naramurti. 2013. Kerjasama Kepolisian dan Penegakan Hukum Internasional. Jakarta: PT. Firris Bahtera Perkasa.

Holtom, Paul. 2010. Prohibiting Arms Transfers to Non-State Actors and the Arms Trade Treaty. Stockholm: SIPRI.

Holtom, Paul and Mark Bromley. 2011. Transit and Trans-shipment Controls in an Arms Trade Treaty. Stockhom: SIPRI.

------. 2011. Implementing an Arms Trade Treaty. Stockholm: SIPRI.

Kytomaki, Elli and Valerie Yankey Wayne. 2006. Five Years of Implementing the United Nations Programme of Action on Small Arms and Light Weapons. Regional Analysis of National Reports UNIDER.

Lisbet, 2014. Masalah-masalah Di Kawasan Menjelang Realisasi Komunitas ASEAN 2015: Peluang Indonesia di Komunitas ASEAN 2015. Cetakan Pertama. Jakarta: Pusat Pengkajian Pengolahan Data dan Informasi (P3DI) Sekretariat Jenderal DPRRI.

LPSK. 2012. Transnational Organized Crime. Bulletin of Kesaksian LPSK. No. III.

Luhulima C.P.F. 2010. Dynamics of Southeast Asia Toward 2015. First Printing. Jakarta: Center of Political Studies (P2P) LIPI.

Maze, Kerry dan Sarah Parker. 2006. International Assistance for Implementing the Programme of Action to Prevent, Combat, 
and Eradicate the Illicit Trade in Small Arms and Light Weapons and it's All Aspects. UNIDIR.

Nurhidayatuloh, et al. 2018. "Forsaking Equality: Examine Indonesia's State Responsibility on Polygamy to the Marriage Rights in CEDAW". Jurnal Dinamika Hukum. Vol. 18 (2).

Parthiana, I Wayan. 2016. Hukum Pidana Internasional. Bandung: CV. Yrama Widya.

SAS. 2010. Small Arms Transfers Control Measures and the Arms Trade Treaty. Cambridge.

Severino, Rodolfo C. 2006. Southeast Asia in Search of an ASEAN Community. Singapore: ISEAS.

Verri, Piettro. 1992. Dictionary of International Law of Armed Conflict. ICRC.

Wezeman, Siemon T. 2009. Arms Transfers to Asia and Oceania. Stockholm: SIPRI.

Yahanan, Annalisa, Febrian, and Rohani Abdul Rahim. 2017. "The Protection of Consumer Rights for Aviation Safety and Security in Indonesia and Malaysia”. Sriwijaya Law Review. $1(1)$.

\section{Internet}

http://www.thomaslfriedman.com/boolshelf /the - lexus - and - the - olive - tree. [retrieved: March 30, 2017]

http://www.un.org/disarmament/wmd/missi les. [retrieved: April 24, 2017].

http://www.un.org.disarmament/wmd/bio. [retrieved: April 24, 2017].

http://www.un.org.disarmament/wmd/chem ical. [retrieved: April 24, 2017].

http://www.un.org/disarmament/wmd/nucle ar. [retrieved: April 24, 2017].

Master Plan on ASEAN Connectivity Association Asian Nations: quoted from:http://www.mfa.fo.th/asean/contents/fi les/asean-media-center-2012-2013-182010779067.pdf. [retreived: April 25, 2017].

UN Convention Against Transnational Crime Tahun 2000. www.undoc.org/undoc/en/organized-crime/index.html. [retrieved: March 30, 2017]. 